DOI: http://dx.doi.org/10.18203/2320-1770.ijrcog20161723

Opinion Article

\title{
The roman catholic church and contraception
}

\author{
William J. LeMaire* \\ Department of Obstetrics and Gynaecology, University of Miami Miller School of Medicine, Miami, Florida, USA
}

Received: 19 April 2016

Accepted: 13 May 2016

*Correspondence:

Dr. William J. LeMaire,

E-mail: awlemaire@hotmail.com

Copyright: ( $\odot$ the author(s), publisher and licensee Medip Academy. This is an open-access article distributed under the terms of the Creative Commons Attribution Non-Commercial License, which permits unrestricted non-commercial use, distribution, and reproduction in any medium, provided the original work is properly cited.

\begin{abstract}
The official position regarding the use of artificial means of family planning varies from religion to religion. With its steadfast opposition to the use of any form of contraception or sterilization, the Roman Catholic Church puts its 1.2 billion followers worldwide in the difficult dilemma of either adhering to the teaching of their church and thereby risk an unwanted pregnancy, or ignoring that teaching and use an artificial method of family planning, but thereby become marginalized by their church. Pope Francis has made a number of statements and actions indicating that their might be a possibility of some changes in the teaching of the Roman Catholic Church regarding a number of issues re-lated to the family, such as divorce, remarriage, gays and women's rights. However he has continued to reaffirm the Church's opposition to the use of any artificial method of family planning and has reiterated on a number of occasions that the Church will only allow the so called natural methods. This essay argues that in the opinion of the author, the time has come for the Roman Catholic hierarchy to revise this outdated position and allow catholics to resort to modern methods for limiting the size of their family, which is some-thing that a large percentage of the catholics are doing already anyway.
\end{abstract}

Keywords: Roman catholic church, Contraception, Natural family planning, Pope Francis

\section{INTRODUCTION}

At no time has an open discussion of the many issues that face the catholic family been more timely.

On April 8th 2016, Pope Francis released his long awaited document on "Love in the Family" (Amoris Laetitia). ${ }^{1}$ In this lengthy and comprehensive document the Pope summarizes the many statements made by himself since his ascendance to the Papacy in 2013 and the often contentious deliberations of the two Synods in Rome in 2014 and 2015 about issues related to the family. In this beautiful and sensitive written document, the Pope touches on issues that impact on the family, including, divorce, gay and lesbian marriage, sexuality and many other aspects of the family. One of the issues discussed by the Pope is family planning and it is on this issue that I would like to focus this discussion.

\section{The dilemma for the catholic practitioner}

The official position of the Roman Catholic Church (Church from here on) has for a long been time that artificial methods of family planning such as condoms and other barrier methods, contraceptive pills, patches and injections or implants, intrauterine devices and sterilization both male and female are opposed. Only the so called natural methods are allowed. ${ }^{2}$ Using or prescribing artificial methods of family planning is considered a grave sin. This official position of the Church impacts not only on individual Catholic couples and patients but also has far reaching consequences for Catholic practitioners, including physicians (MD or DO), midwives, nurses, nurse practitioners, physician assistants and even health aides and anyone involved with the advice, prescription, injection, implantation or insertion of contraceptive medication or devices as well as male or female sterilization. 
If the catholic medical practitioner elects to adhere to the teaching of the Church in this regard, he or she may be denying their clients the effective methods of that they so desperately want and need.

Another option for the practitioner is to ignore the teaching of the Church and continue to provide their clients with the effective methods they desire. In doing so they may feel marginalized by the Church to which they belong. A third option is to go ahead and prescribe, for instance oral contraceptives, for the stated reason, that they are prescribed "to regulate her periods", and not for birth control per se. I have witnessed this bogus indication applied a number of times in a catholic setting. This approach is of course dishonest and makes a "liar" out of the practitioner involved. A final option would be to refer the client to another practitioner who may not be burdened by religious constraints. While that option is available in most settings in the developed world, it is often not available or completely impractical in developing countries.

\section{Natural versus artificial methods of family planning}

The Natural Methods of Family Planning (NFP) allowed by the Church, also called the Fertility Awareness Based Methods or FABM work very well under ideal circumstances when practiced by dedicated and educated couples. They are based on the concept that pregnancy will not occur if intercourse is avoided during the fertile period of the woman's menstrual cycle (ovulation). Medical advances have made the determination of this fertile period much more reliable and many catholic couples throughout the world use these methods very successfully and with satisfaction. A certain amount of education and dedication on the part of both husband and wife is still required and regular menstrual cycles are not essential but certainly very helpful in making these natural methods effective. ${ }^{3}$ Under less than ideal circumstances however, these natural methods have a high, and I might add an unacceptable failure rate. ${ }^{4}$

This is especially true in developing areas of the world where extreme poverty is the norm, living conditions are abysmal, literacy is quasi nonexistent, women often have very irregular menstrual cycles, and medical care is mostly not available. Natural methods are just not practical under these circumstances. There is abundant evidence that large numbers of catholics around the world are ignoring the teaching of their church when it comes to family planning. ${ }^{5}$

Thus it seems that allowing more effective methods of planning a family, especially in these areas of the world where the natural methods may have a high failure rate would be a welcome change in the teaching of the church. Proponents of the natural methods often will argue that some methods of contraception might actual operate by preventing implantation of a fertilized ovum, and thus could be considered abortifacients, which is certainly unacceptable to the Church. I would acknowledge that some of these artificial methods on occasion may alter the lining of the uterus to the point that an ovum, if fertilized anyway, will not implant (abortifacient?). The majority of evidence however points to the fact that these methods prevent sperm transport and/or ovulation, rather than prevent implantation and therefore should not be considered abortifacients in the vast majority of instances. 6,7

One other argument that is often raised in this type of discussion is that artificial methods of family planning have serious side effects. I acknowledge that that may be so, even though the risks are small. As an example, the relative risk for a serious venous thromboembolic event for women using the combined oral contraceptive pill is certainly increased, but the absolute risk is very small. ${ }^{8}$ However an issue that is mostly overlooked, is the complication rate of failed contraception resulting in a pregnancy. As I argued earlier, that failure rate is considerably higher for natural methods when applied to the overall world population. An unwanted pregnancy, or any pregnancy for that matter, especially in developing countries carries with it the risk of serious morbidity and even mortality associated with the pregnancy and delivery. Thus natural methods of family planning are not devoid of side effects, although indirect. ${ }^{9}$

\section{Statements by Pope Francis about family planning}

Ever since Jorge Mario Bergoglio ascended to the Papacy in 2013 and became our beloved Pope Francis, Catholics all over the world have had high hopes for reforms in the Catholic Church in matters of the family. Everywhere Pope Francis has gone he has had some promising words to say about issues related to the family. Some of these statements may have seem impossible only a few years ago. To mention only a few of these comments, here is one on gay people, "If someone is gay and he searches for the Lord and has good will, who am I to judge?"10 Talking recently about divorced couples Pope Francis said: "they (divorced couples) are not excommunicated, and they absolutely must not be treated that way!",11 Then during a recent general audience in Rome Pope Francis came out very strongly in favor of women's equality. ${ }^{12}$

The two synods held in the Vatican in the fall of 2014 and 2015 and convened by Pope Francis to discuss these issues pertaining to the family apparently were very contentious without any definitive resolution of problems. That is to say until just April this year with the release of the Pope's exhortation "Amoris Laetitia", in which he addresses and summarizes his and the Church's views and teaching about many issues of the family. While the tone of this lengthy paper (called exhortation) is certainly very reconciliatory, it fails to very clearly resolve any of these issues. ${ }^{1}$ 
Pope Francis has also made some less encouraging comments about family planning. ${ }^{13}$ On his flight back from a visit to the Philippines in January of 2015 he stated that catholic couples are free to plan the number of children they have according to their means and should not reproduce indiscriminately. That was somewhat of an unprecedented statement by a Pope and very welcome to catholic couples throughout the world. However, in the same interview he reaffirmed the Church's teaching on family planning as was formulated by Pope Paul VI in his encyclical of 1958 "Humanae Vitae". And then in "Amoris Leatitia" he again reiterated the Church's opposition to artificial methods of family planning. ${ }^{1}$ This position of the Pope and the Church in regards to family planning is certainly very disappointing to many catholics around the world and with his remarks on family planning Pope Francis may have caused some confusion amongst many catholics. While he tells married couples that it is all right, and in fact advisable to limit the number of children they have, he denies them the effective methods to do so. That seems a bit unfair.

Equality for women, strongly advocated by Pope Francis with his statement that “... continuing disparities in pay for women are a pure scandal ...." reproductive rights, was between us and eloquently argued by Jessica Valenti in recent opinion article in The Guardian. ${ }^{14}$ Further more Eve Espy in the Irish Cushner Memorial Lecture at the 2014 annual Clinical meeting of the American College of Obstetricians and Gynecologists made a strong point for the moral imperative of contraception but without belaboring the religious aspect of this issue. ${ }^{15}$

\section{Will/can the church change its position on family planning?}

All the pronouncements regarding divorce, remarriage, gays, women's rights seem to indicate that Pope Francis is willing too listen and that may be, just may be some needed changes and modernization in the teachings of the Church in regards to some of these issues might be forthcoming. Why then can the problem of family planning not be included in the discussion of possible changes in the Church's teaching. Without being an expert in the interpretation of the bible, it seems from my readings that the only direct reference in the scriptures to contraception is the story of Onan, who spilled his seed on the ground to avoid a pregnancy of his brother's widow (Tamar) whom he had married as was required by the Levirate law. God punished Onan by death for his action. The interpretation of that passage has certainly been open for interpretation by biblical experts. ${ }^{16}$ One such interpretation is that the Lord punished Onan for practicing a form of artificial family planning (withdrawal). An other interpretation, favored by a number of theologians is that Onan was punished because of greed. He wanted to avoid producing a heir to his brother's estate, so that he could be the sole beneficiary. Because of this he was punished by death and not because his use of a form of contraception. It seems then to me that the use of this passage of the bible to support an opposition to contraception is problematic.

By changing its teaching about family planning and allowing effective methods of contraception, the Catholic Church could have a major impact on many current and important issues facing the world. Lack of availability of effective methods of contraception results in unwanted births, which leads to overpopulation especially in areas of poverty, famine, lack of basic needs and medical care; areas that can least afford this overpopulation. Overpopulation, directly or indirectly seems to be at the basis of, or at least contribute to many of the current problems facing the world, such as famine, illiteracy, violence, crime, war, and climate change. I am fully aware of the complicated matter of overpopulation as many areas in the world are actually seeing a major decline on births and are indeed heading towards "underpopulation", with its serious implications. ${ }^{17}$ Yet the need for effective contraception continues to exist. I might add that it is likely that allowing and promoting effective methods of birth control will undoubtedly reduce the number of abortions by reducing unwanted pregnancies worldwide.

Furthermore, by changing its position on family planning and allowing the use of effective methods of contraception the Catholic Church would also make it possible for the millions of catholics around the world who are already ignoring the teaching of their Church in this regard and are openly using or advocating artificial methods of family planning to return to the fold. These people, including me, would no longer feel marginalized by their Church. I sincerely hope that under the reign of Pope Francis such a change might still come about.

Many of the catholic priests, with whom I have discussed this issue will tell me to ignore the Church's teaching, follow my conscience, and continue with my practice of prescribing artificial methods of contraception and carrying out permanent sterilization procedures. This approach has also been advocated by some theologians. ${ }^{18}$ That is of course just fine for me, and many others, but in the overall picture of things, it makes no sense. If rules, regulations, and laws are such that a vast majority of people, including those in position of authority are ignoring them, is it then not time for the leadership to seriously review and hopefully modify the rules? That, to me and to many of my catholic colleagues and patients, seems only logical.

Many devout Catholics will argue that it should be the other way around. That the millions of catholics around the world who currently are using or prescribing artificial methods of contraception should abandon this practice in favor of the natural methods allowed by the Church. To be absolutely practical, that is not going to happen as I have attempted to point out. 
Funding: No funding sources

Conflict of interest: None declared

Ethical approval: Not required

\section{REFERENCES}

1. "Contraceptive Use in the United States" Guttmacher Institute Fact Sheet October 2015. Available at https://www.guttmacher.org/pubs/fb_contr_use.html ?gclid=Cj0KEQjw6vquBRCow62uo_J_YYBEiQAMO6HiuZs6szIhVoisX_oZfjfFLmZB WyPYTt-hskh6SJXxhIaAi9q8P8HAQ\#6. Accessed April 192016.

2. Guttmacher Statistics on Catholic Women's Contraceptive Use. February 15, 2015. Available at: http://www.guttmacher.org/media/inthenews/2012/0 2/15/. Accessed 19 April 2016

3. Rivera R, Yacolson I, Grimes D. The Mechanism of Action of Hormonal Contraceptives and Intra Uterine Devices. Am J Obstet Gynecol. 1999;181:1263-9

4. Haley Willacy. Contraception - General Overview. PatientPlus. May 11, 2012. Available at http://patient.info/doctor/contraception-generaloverview. Accessed 19 April 2016.

5. Royal College of Obstetricians and Gynecologists. Venous Thromboembolism and Hormonal Contraception. July 2010. Available at: https://www.rcog.org.uk/globalassets/documents/gui delines/gtg40venousthromboembolism0910.pdf. Accessed 19 April 2016.

6. WHO. Maternal Mortality. May 2014. Available at: http://www.who.int/mediacentre/factsheets/fs348/en. Accessed 19April 2016.

7. Allen J, Messia H. Pope Francis on Gays: "who am I to Judge". Available at: http://religion.blogs.cnn.com /2013/07/29/ pope-francis- on-gays-who- am-i-tojudge/ Accessed 19April 2016.
8. Gibson D. Pope Francis says Church must welcome divorced, remarried catholics. August 5, 2016. Available at: http://www.religionnews.com /2015/08/05/ pope-francis- says- the-church- mustwelcome-divorced-and-remarried-catholics/.

Accessed 19 April 2016

9. Nolan Feeney. Pope Francis calls for equal pay for women and men. April 29 2014. Available at: http://time.com/3840049/pope-francis-equal-pay/. Accessed 19 April 2016

10. Gibson D. Don't breed like rabbits: Was Pope Francis breaking new ground on birth control; January $212015 . \quad$ Available at http://ncronline.org/news/vatican/dont-breed-rabbitswas-pope-francis-breaking-new-ground-birthcontrol. Accessed 19 April 2016

11. Valenti J. "If the Pope Wants Women's Equality, He Must Support Reproductive Rights". The Guardian 04/30/2015. Available at http://www.theguardian.com/commentisfree/2015/ap r/30/pope-women-equality-wage-gap-reproductiverights. Accessed 19April 2016

12. Espey E. Feminism and the Moral Imperative For Contraception. Obstetrics and Gynecology 2015; 125: 396-402

13. Got Questions? "What Does the bible Say About Birth Control? Should Christians Use Birth Control" $2015 . \quad$ Available at: http://www.gotquestions.org/birth-control.html. Accessed 19 April 2016.

14. Kelly K. "What should we be worried about", Edge 2013. Available at: https://edge.org/responsedetail/23722. Accessed 19 April 2016

15. McElwee JJ. Theologians call Church sexual teachings 'incomprehensible', ask for lay input. National Catholic Reporter 11/21/2013. Available at http://ncronline.org/blogs/ncr-today/theologians-callchurch-sexual-teachings-incomprehensible-ask-layinput. Accessed 25 May 2016.

Cite this article as: LeMaire WJ. The roman catholic church and contraception. Int J Reprod Contracept Obstet Gynecol 2016;5:2065-8. 